\title{
The Analysis of H.O.S Tjokroaminoto's Figure Values in Historical Prespective
}

\author{
Septian Teguh Wijiyanto ${ }^{1}$, Prof. Ajat Sudrajat, M.Ag. ${ }^{2}$ \\ History Education Pascasarjana, Yogyakarta State University, Yogyakarta, Indonesia \\ 1'septiantw209@gmail.com,2ajat@uny.ac.id
}

\begin{abstract}
This study aims to: (1) reveal the background of Tjokroaminoto's life; (2) analyzing the role of Tjokroaminoto in Indonesia's historical trajectory; (3) examines the values of Tjokroaminoto's figures; (4) analyze how the values of Tjokroaminoto's figure can be actualized in historical learning in schools. This research is qualitative study with historical approach. The subject and object of this study are related to the dimension of history, so it is necessary to reconstruct with a historical method. This study employed a document study consisting of primary and secondary sources. In addition, it also used interviews as reinforcement. The result shows that, the first: Tjokroaminoto was born and grew up in an environment close to Islam. He attended school at OSVIA Magelang, which took him to become a civil servant. Tjokroaminoto prefered to leave his establishment and fight against colonialism. The second, Tjokroaminoto chose to join the SDI organization, turning SDI into SI and having political orientation. Tjokroaminoto succeeded in becoming the leader of SI and bringing SI into a large and influential organization. He used the Islamic value in every struggle both in politics and education. The third, Tjokroaminoto's figure values that can be exemplary are leadership, independence, courage to take risks, orientation to action, and hard work. All of these values are manifested in Tjokroaminoto's daily life. The fourth, the actualization of Tjokroaminoto's figure values in order to contribute to the world of education is realized in the hope that can inspire the teachers of history that teaching history does not only present a series of facts and events, but the teachers build understanding and awareness for students about the meaning behind the events, including values what values are contained in these historical events.
\end{abstract}

Keywords: Figure, Tjokroaminoto, Historicallly.

\section{Introduction}

A nation's life could only become more advanced, modern, and prosperous through great education system. According to law number 20, article number one, 2003, stated that education is an attempt of an individual to develop their potency, so that they could have intelligence, good morale, good religion understanding that benefits themselves and their country.The management and goals of education in Indonesia has been ruled by law number 20, 2003 on chapter II article 3, stated: education's goal is to shape an individual to become an individual with devotion to God, a good morale, high level capability, independent, critical, and democratic. Education could help a person to be able to decide a choice through thinking, behaving, and acting [1].

Ki Hadjar explains that in order to accomplish things, like (1) steps in education have to fit its nature, (2) "kodrat" is part of culture and society, (3) that culture have always been fitted with changing times, (4) past of a country really determined its today's condition, (5) mix 
between countries often are easily occur because modern way of modern relations, so we need wisdom and savviness in order to picking the right choices [2].National education as the way to transforming, civilizing, developing, and empowering students is not yet able to shaped a citizen with complete Indonesian characteristic. It shows by crisis of role model, low level of national identity, and multiple social problems. Indonesia seems have to lost character and national identity that has been built by its ancestors, heroes, and previous national figures [3]. This country seems unable to shows a characteristic of a solid, hardworking nation: honest, loving, empathetic, and developing togetherness that supports every nation's component. Symbol and value of Pancasila such as, religiousness, humanism, politeness, peace loving, togetherness, willing to sacrifice, and love for the motherland are forgotten.

History learning in application of 2013 Curriculum have strategic role. History learning is hoped to be able to build character values in students. If historical facts could be dug up deeper and seen from what behind it, it could be very useful[4]. Sardiman explains that learning history could give examples to follow in today's life so that it could give enlightenment for future. History are full of morale lessons. Thomas Holt stated that history shouldn't displayed as compilation of facts, but rather become something developed and accepting different point of views.One of history key point which its value could be dug up deeper is human or figure. In history there are a lot of important events which its figure values could be dug up more. In further study of character value as inspiration and example in education, Haji Oemar Said Tjokroaminoto's will be written Tjokroaminoto in further parts character value can be analysed. Tjokroaminoto often called as "national teacher" because his acts and thoughts can be used until this day.

Studies or analyses about character values of a hero in historical facts are low. Studies about Tjokroaminoto always focused on his role in politics, even though other sides of Tjoroaminoto are interesting to analysed even further. Even though his values are still relevant with today's condition.

\section{Research Methods}

Research type that being used is historic-qualitative. Analyses of character values need to be studied with those two methods so that the values have valid data. This thing need to be done so that data that already gathered can be verified, so when qualitative method is being used there are no data from historic method. Research with historical approach that continued with analyses about Tjokroaminoto's values can be actualised in history subject in school especially in topic of national movements or specifically taught topic about Tjokroaminoto.

Analyses about Tjokroaminoto including thoughts, acts, and struggles in society. Subject and objects that been analysed related with historic dimension, hence this research needs reconstruction with history research methods or historiography. Therefore, this research used qualitative research with history methodologic approach. That in this research, data that have been found needs to be analysed with historic methods, because facts that have been found are historic facts that needs to be reconstructed and arranged chronologically [5].

\subsection{Place and Time of Research}

This research is completed by analysing Tjokroaminoto's writings and other writings about Tjokroaminoto. Research took place from January until June 2019. Supporting data that have 
been gathered, came from multiple scientific writings, research, and documents that have correlation with Tjokroaminoto in which then analysed as source or secondary data.

Literature studies are done in order to collect necessary data by visiting: (1) Yogyakarta State University Library, (2) Yogyakarta Regional Library, (3) Yogyakarta Regional Archive, (4) Gadjah Mada University Library, and (5) Yogyakarta UIN Sunan Kalijaga Library.

\subsection{Data Source}

Data source in this research came from primary source and secondary source. Primary source is collected from the person itself or other person that saw the event. Whereas secondary source is other people's creation [6]. That primary source, also called as real source created during events of history. Hence, primary source is a source that gathered or collected from testimony or explanation from the subject or witnesses that really witness the event with its own senses.

\subsection{Data Collecting Technique and Instrument}

Parallel with Sugiyono's opinion data collecting technique is important step in research to do in order to collect data. Kaelan explains that observation, interview, and documentation is important to note during collecting data in qualitative research. Object in analyses is Tjokroaminoto's character values. Therefore, observation is completed with gathering data or information about Tjokroaminoto.

Kaelan stated that main instrument of analyses is human instrument. Research problems fitted with research purpose so that the researchers able to arrange instrument of collecting data. Theories about Tjokroaminoto's character values became the basis of arrangement of data collecting instrument. Rubric of analyses then used as guide of collecting data.

Table 1. Lattice of Instrument Values for Tjokroaminoto Figure

\begin{tabular}{lll}
\hline No. & Analyzed Aspects & Indicator \\
\hline 1 & Leadership & $\begin{array}{l}\text { The attitude and behavior of someone who is able to organize, } \\
\text { direct others, powerful, and has the ability to actuate. } \\
\text { The attitude and behavior that can accomplish tasks without } \\
\text { needing help from others. }\end{array}$ \\
2 & $\begin{array}{l}\text { Independence } \\
\text { The attitude and behavior of someone who dares to act and } \\
\text { faces all of the consequences that arise thereafter. } \\
3\end{array}$ & $\begin{array}{l}\text { Dare to Take } \\
\text { Risks }\end{array}$ \\
4 & $\begin{array}{l}\text { Orientation to The } \\
\text { Action }\end{array}$ & $\begin{array}{l}\text { can be done in other words is able to take the initiative. } \\
\text { The attitude and behavior that show sincerity and seriousness } \\
\text { in overcoming something. }\end{array}$ \\
\hline
\end{tabular}

\subsection{Source of Criticism}

Kuntowijoyo explained further that source of criticism is an activity that includes testing, evaluating, and selecting sources collected to obtain original sources. Investigation activities to test whether the sources obtained in the heuristic stage can be used in the research that we do or not to find truth in history, but the process of finding facts that are close to the truth, which is true, not true, or impossible. The source criticism consisted of external and internal criticism. External critisism is testing of data obtained based on time. Source of criticism has 
the aim to test the authenticity of the data source by comparing it with other sources. The things tested in this external criticism can refer to $5 \mathrm{~W} 1 \mathrm{H}$. The way is by examining the physical form or external aspects from the source used [7].

While internal criticism is testing data based on the quality, form, credibility of the data. It means that internal criticism actually refers to the physical aspects of the data. In addition, in order for the source to be credible, it must be believed that the chosen source does indeed contain information that shows important events that are widely known to the wider community. Kuntowijoyo explained that the verification carried out really need accuracy, caution, and focus of the researchers themselves. The data collected can be verified valid, both in terms of content and physical by paying attention to internal and external aspects in accordance with the verification carried out.

\subsection{Data Analysis Technique}

Interpretation is the stage where researcher begins to translate or explain the data obtained after criticizing the source. Interpretation is often divided into two stages, namely analysis and synthesis [8]. Analysis more refers to the data collected which is described in general then spesifically. It is complex so the other aspects can also be included in it. While synthesis is the process of bringing together analyzes from historical sources in order to achieve research objectives. Helius Sjamsudddin explained further that the process of interpretation really need heurmenetics and verstehen.

It can greatly affect the researchers because the aspects of the value that will be formulated can not be separated from the background and behavior of the researchers themselves. It means that in conducting this stage, researchers must be able to identify well, be objective, and fair without having any tendencies in their research. Hermeneutics can be used by researchers to develop creativity and openness so it can obtain a fuller understanding.Verstehen is implemented to revive or re-project the experience of other subjects so that the subject can be the object of research. These data finally reached a conclusion [9].

\section{Result And Discussion}

Oemar Said Tjokroaminoto was born in Bakur Village, Madiun, East Java on August 16, 1882. Oemar Said is a name that commonly used since his childhood, later better known as Tjokroaminoto[10]. Tjokro has a lineage of clerics and nobles at the same time, from his great-grandfather who is a great scholar, Kyai Bagus Kasan Besar. His grandfather was married to the princess of the Surakarta Palace, who is the daughter of Susuhunan Paku Buwono III. Islamic-javanese noble blood is very thick in Tjokroaminoto and his family[11].Tjokroaminoto's grandfather, Tjokronegoro, is a Regent of Ponorogo. Ponorogo is one of the places where the conflicts often occur. At that time, Tjokronegoro was respected by the community and considered as a leader who brought safety and prosperity. His father, Tjokroamiseno is a Dutch civil servant in Madiun.

$\mathrm{He}$ is twelve brothers, they are: Raden Mas Oemar Djaman Tjkroprawiro, Raden Mas Oemar Said Tjokroaminoto, Raden Ayu Tjokrodisoerjo, Raden Mas Poerwadi Tjokrosoeprodjo, Raden Mas Oemar Sabib Tjokrosoeprodjo, Raden Ajeng Adiati, Raden Ayu Mamowinoto, Raden Mas Abikoesno Tjokrosoejoso, Raden Ajeng Istingatin, Raden Mas Poewoto, Raden Adjeng Istidja Tjokrosoedarmo, and Raden Ayu Istirah Mohammad 
Soebari[12]. Many of Tjokroaminoto's siblings followed in the footsteps of his father and grandfather as civil servants in various regions, but there were some of his siblings who followed in the footsteps of Tjokro in the national movement namely Oemar Sabib and Abikoesno Tjokrosoejoso.

In 1902, Tjokroaminoto married a royal descent, Raden Ayu Soeharsikin. She is a daughter of Raden Mas Mangoensoemo, the vice regent of Ponorogo. His marriage to R.A. Soeharsikin was blessed with five children namely Siti Oetari (later becoming Sukarno's wife), Oetarjo aka Anwar, Harsono aka Moestafa Kamil, Siti Islamijah and Soejar Ahmad [13]. Soeharsikin was an important and influential figure for Tjokroaminoto's personality, although in its development there was a conflict between Tjokro and his parents-in-law, but it did not affect the harmony of Tjokro and Soeharsikin's relationship.

In 1897 Tjokroaminoto finished his school at the elementary level of a Dutch school. In here Tjokroaminoto could master Dutch quite well. Raden Mas Tirtoamiseno put Tjokroaminoto in OSVIA (Opleiding School voor Indlandsche Ambtenaren), which is a school for prospective government employees for native Indonesian located in Magelang, Central Java. Tjokroaminoto was schooled there to become a government employee or Binnenland Bestuur (BB). This is naturally done by noble parents who used to put their children into OSVIA[14]. Those parents hoped that their children have a guaranteed future by being a civil servant. That's why OSVIA became a school that was coveted by the parents with noble background.

\subsection{Role of Tjokro in Indonesia's Historical Path}

Haji Samanhudi asked Tjokroaminoto to act as a compiler of his trade group organization, so that his organization could be legalized by the Netherlands Indies Government[15]. Tjokroaminoto agreed and then made a legal deed for a new organization called Sarekat Islam. The legal deed was made in his own name on September 10, 1912. Thus the SI was formally established. SI was a successful organization in the Dutch East Indies at the beginning of the national revival.

The change of the name SDI to SI had a membership goal that was not only intended for traders, but was expanded to cover all community activities. Tjokro replaced H. Samanhudi as a SI leader at the SI congress in Yogyakarta on 18 February 1914. SI was decided to be an organization that had national reach. It means that SI had become an organization that had the largest mass base at that time, with its members and branches are all over the Dutch East Indies. SI has a fairly brave step by campaigning Zelfbestuur (self-government) which is independent of the Dutch Government.

SI's willing to form Zelfbestuur is a response against Hindia Belanda Government. SI wanted to be involved and participated in politics. SI wanted to be involved in the making of important decisions in Hindia Belanda. Tjokro wants people of bumiputra gain rights to participate in taking decisions of laws and rules made by Hindia Belanda Government[16]. Tjokro is able to bring SI to as a large organization with a lot of mass basis. Agus Salim one of the reasons that SI is quickly developing because they offering new idea about nationalism and freedom.Agus Salim adds that SI was accepted among society because Tjokro's struggle to gain recognition from Dutch Government [17]. But, Hindia Belanda Government still keep their eyes on every movement of SI. SI under Tjokro have massive impact to the society, people hail and idolize Tjokro. In agriculture society, there is a concept of "Ratu Adil", a presumption about a leader who could lead society to become more prosperous. 
Anhar Gongong said that Tjokroaminoto is the first leader that openly stated about foundation of laws in case of people are being given freedom to choose their own status. Tjokroaminoto through SI "asked" the Hindia Belanda Government to give more chances for native Indonesian to create their own government. During the opening of first congress Central Sarekat Islam in 1916, Tjokro stated that he wants to build an independent democratic based government. Democracy in Tjokro's view have to fit Islam laws. He shows his way of democracy during his leadership in SI.Friction in SI internals encourage Tjokroaminoto to take action. As a democratic person, he tries to mediate and avoid any future friction in his movement. By initiating "Islam Socialism", he represents the two sides. The idea later written as a book, "Islam and Socialism" in 1924. One of the main purpose of the book is to explains that Islam have the similar lessons and principle with socialism[18].

Tjokroaminoto's thought are heavily influenced by educational system of Hindia Belanda Government. Education opportunity are not given for all people of Hindia Belanda. A lot of schools from Hindia Belanda Government didn't have religion subject, especially Islam. This situation cause Tjokroaminoto to criticize education problems during Hindia Belanda times.Tjokroaminoto is taught with education with strong Islam values. Islam became Tjokro's basis of mindset, acts, and also his view of education [19]. Education is the way to elevate someone's status and prosperity, but education must be checked from its basis. Religion became a strong and important basis in education concept[20]. Education system in those schools refers to Tjokroaminoto's work called Moeslim Nationale Onderwijs, roughly translated as Islam based national teaching method.

\subsection{Heroism Values of Tjokroaminoto}

His heroism values are important to study and dug deeply. It's because his own role in heroism. Studying his heroism equal as studying history of his role and thought. Learning history is a continued social reality and dialogue. Therefore, as explained before, studying history is a sign of historical awareness.

\subsection{Leadership}

Tjokroaminoto's leadership role was seen clearly when he led SI and brought it as a large organization and influential in Hindia Belanda. His ideology about democracy, nationalism, and Islam-socialism became basis of SI movements. Tjokroaminoto able to exceeds his own needs by putting people's needs first. His leadership are influencing other cadre.

\subsection{Independence}

Tjokroaminoto proves that he's not just Anti-Dutch in his thoughts and acts, but he is willing to abandon his noble title for fighting among people. His independency is taught through SI by demanding freedom and built independent government (Zelfbestuur).

\subsection{Willing to Take Risks}

Tjokroaminoto took brave big step by changing basis of SI's ideology to became more political. Tjokroaminoto openly formed people and led them to freedom from Dutch colonialism. During his journey when SI have internal clashes, Tjokroaminoto dare to take step and applying organization rules that led to SI's fraction. 


\subsection{Oriented in Taking Action}

Ideas, thoughts, opinions from Tjokroaminoto is manifested in real actions. He is a figure that became example for his followers. His idea about education he manifested in Moeslim National Onderwijs as basis of education at that time. His writing about Islam Socialism is a strategic plan. During that time, there are lot of clashes between ideologies. Tjokroaminoto able to do real action to face multiple problems.

\subsection{Hard Work}

Tjokroaminoto's hard work to fulfilled basic needs of his family are shown when he is working at a company and a sugar factory. SI's growth came from his effort in gaining supports and spreading his ideas. When SI's fractioned, he also tried everything that he could to avoid it.

\subsection{Actualisation of Heroism Values in Education}

Actualisation of Tjokroaminoto's heroism values in education, especially in history subject is expected to become inspiration for history teacher to build student's awareness and understanding about lessons from history. Including in studying history's element which is the person or the figure, its values can be dug up. As for Tjokroaminoto's heroism values can be taught in history subject in $11^{\text {th }}$ grade in basic competencies 3.6 about role of national heroes and local heroes in Indonesian freedom or it could be taught during topic of History of National Movement.

\section{Conclusion}

Tjokroaminoto grew in a noble family with strong Islam influence. Tjokroaminoto became a figure with great understanding of religion because the influence of his religious family. Tjokroaminoto went to OSVIA, a school built by Hindia Belanda Government that later brought him as a pangreh praja. Tjokroaminoto prefers to leave his nobility and also as a Dutch Government official. People's condition at the time encourage him to stand against Dutch colonialism

Tjokroaminoto prefers to join Sarekat Dagang Islam as a way for his resistance against colonialism. He was chosen as SI leader and led SI to became the biggest organization in Hindia Belanda and also have a big influence. Islam values become the basis of Tjokroaminoto's resistance whether it is in politics or education. Tjokroaminoto is able to mix western thoughts and Islam thoughts fitted with society's condition at that time. He is able to give guidance for his successor in actualizing his dream of independent Indonesia.

Studies and analyses about figures with good character, especially history figures could be added more as it can be an inspiration and role model in society. Just like studies about Tjokroaminoto, even though he is a famous political figures and a religious leader, his thoughts, acts, and resistance still relevant with today's condition.In education point of view, these analyses of heroism values are hoped could give example and inspiration in history learning. Heroism values are expected to give influence to students about figures or heroes with a lot of values to copy. Heroism values could shape an individual, shape their character and morale that they eventually will be able to pick an act or attitude that fit in nation's life. 


\section{References}

[1] Mulyasa, Manajemen Pendidikan Karakter. Jakarta: Bumi Aksara, pp. 4-6, 2011.

[2] K.H. Dewantara, Karya Ki Hadjar Dewantara, Bagian Pertama: Pendidikan. Yogyakarta: Majelis Luhur Persatuan Tamansiswa, pp. 14-15, 1977.

[3] Sardiman, Nilai-Nilai Ketokohan Soedirman dan Sumbangannya terhadap Bidang Pendidikan: Sebuah Studi historis. Disertasi, tidak diterbitkan, Universitas Negeri Yogyakarta, Yogyakarta, pp. 15-16, 2017.

[4] Sjamsuddin, Metodologi Sejarah. Jakarta: Depdikbud, pp. 190, 1996.

[5] Kaelan, Metode Penelitian Kualitatif Bidang Filsafat. Yogyakarta: Paradigma, pp.90, 2005.

[6] Gottschalk,Understanding History: A Primer of Historical Method. Dalam buku Nugroho Notosusanto, Mengerti sejarah. Jakarta: Universitas Indonesia Press, pp.35, 1975.

[7] Kuntowijoyo, Pengantar Ilmu Sejarah. Yogyakarta: PT. Bentang Pustaka, pp. 91, 2005.

[8] Kuntowijoyo, Pengantar Ilmu Sejarah. Yogyakarta: PT. Bentang Pustaka, pp. 78, 2005.

[9] Kuntowijoyo, Pengantar Ilmu Sejarah. Yogyakarta: PT. Bentang Pustaka, pp. 79, 2005.

[10] Amelz, H.O.S Tjokroaminoto Hidup dan Perjuangannya. Jakarta: Bulan Bintang, pp. 50, 1952.

[11] Aziz, Islam, Sosialisme dan Politik Prespektif Pemikiran Tjokroaminoto. Jurnal risalah pendidikan dan studi Islam, vol.4, no.2, pp.1, 2018.

[12] Amelz, H.O.S Tjokroaminoto Hidup dan Perjuangannya. Jakarta: Bulan Bintang, pp. 48-50, 1952.

[13] Mulawarman, Jang Oetama: Jejak dan Perjuangan H.O.S Tjokroaminoto Cet. 1. Yogyakarta: Galang Pustaka, pp. 16, 2015.

[14] Marihandono, pp.77, 2015.

[15] Yasmis, Sarikat Islam dalam Pergerakan Nasional(1912-1927). Jurnal sejarah lontar, vol.6, no. 1, pp. 25, 2009.

[16] Noer, Gerakan Modern Islam di Indonesia 1900-1942. Jakarta: LP3ES, pp. 126, 1982.

[17] Agus Salim, Haji Oemar Said Cokroaminoto cet 1. Bandung: Nuansa, pp.37, 2007.

[18] Anhar Gongong, Tjokroaminoto: Rumah Ideologi dan Dialog. Dalam B. Setyarso, dkk. (Eds), Tjokroaminoto Guru Para Pendiri Bangsa. Jakarta: KPG, pp. 126-132, 2011.

[19]. Sayyidah Mawani, HOS Tjokroaminoto. Yogyakarta: Sociality, pp. 169, 2017. "during his life, Tjokroaminoto is taught with education with strong Islam values. Islam became Tjokro's basis of mindset, acts, and also his view of education."

[20] Setyarso, Seri Buku Tempo Tjokroaminoto. Jakarta: Kepustakaan Populer Gramedia, pp. 28, 2011. 